\title{
A FUNÇÃO SOCIAL DOS CONTRATOS À LUZ DE SEUS PARADIGMAS CONFLITANTES: JUSTIÇA DISTRIBUTIVA X EFICIÊNCIA ECONÔMICA
}

THE SOCIAL FUNCTION OF CONTRACTS IN THE LIGHT OF THEIR CONFLITING PARADIGMS: DISTRIBUTIVE JUSTICE X ECONOMIC EFFI-

\section{RESUMO}

Este trabalho propõe-se a analisar a função social do contrato sob dois espectros, quais sejam: justiça distributiva e eficiência econômica, buscando delimitar tais conceitos e revelar a interpretação mais favorável ao espaço público de mercado e a segurança jurídica. Faz-se um paralelo acerca da fundamentação das decisões judiciais no âmbito empresarial, verificando a interpretação dos juízes ao adotar os diferentes paradigmas e os reflexos ocasionados ao ambiente de mercado. Ao final, salientamos que a função social do contrato à luz da eficiência econômica mostra-se, a nosso ver, a mais prudente.

\footnotetext{
${ }^{1}$ Pós-graduada em Direito Empresarial pela FGV-Direito/SP. Advogada - Escritório Salusse Marangoni. E-mail: tha_abra@hotmail.com
} 
Palavras-chave: Função social do contrato. Justiça distributiva. Eficiência econômica. Interpretação. Decisões judiciais.

\section{INTRODUÇÃO}

O direito privado evoluiu consideravelmente nas últimas décadas, neste sentido, o atual Código Civil apresenta-se como um estatuto comprometido com a diretriz constitucional da solidariedade. Nota-se que o legislador, motivado pelos avanços e reflexos advindos da Carta da República, introduz uma nova principiologia ao direito contratual.

Neste contexto, o sentido social apresenta-se como característica marcante deste diploma ao dispor em seu artigo 421: "a liberdade de contratar será exercida em razão e nos limites da função social do contrato".

No presente trabalho, a função social do contrato será abordada sob dois prismas conflitantes, quais sejam: justiça distributiva e eficiência econômica. A notável divergência em torno da interpretação do artigo 421 do Código Civil de 2002 nos conduz a uma análise do instituto, atentandose para os efeitos e reflexos que cada um desses paradigmas irá apresentar no espaço público de mercado. Pretende-se, deste modo, revelar a inteligência prestável à função social dos contratos no âmbito do direito contratual empresarial.

Em razão da fluidez do artigo 421 do Código Civil, o intérprete terá a árdua missão de trazer a lume o real significado da função social do contrato. Ressalta-se que, ao longo deste trabalho, a atividade exegética deve ser realizada com prudência e razoabilidade, sob pena de conspurcar o ideal objetivado pelo legislador ao elaborar a norma.

O primeiro capítulo apresenta uma visão panorâmica sobre o tema, no qual evidenciará o compromisso do direito contratual com a ideologia constitucional, bem como os benefícios e malefícios oriundos das cláusulas abertas, em especial da função social dos contratos. A cláusula aberta é um instrumento utilizado pelo legislador para estimular a convivência com as normas constitucionais, neste sentido, a textura fluida atribuída a alguns institutos presentes no novo Código Civil tem como objetivo conferir ao magistrado um mandato para complementar as normas jurídicas de maneira razoável e adequada ao caso concreto. Ressalta-se, contudo, que a atividade exegética do magistrado deve ser realizada com parcimônia, na medida em que as decisões judiciais são standars 
paradigmáticos para outras situações semelhantes. Por fim, apresentamos uma breve noção sobre a função social dos contratos sob a ótica dos dois paradigmas conflitantes: justiça distributiva e eficiência econômica, os quais serão analisados nos capítulos seguintes.

O segundo capítulo apresenta a função social do contrato sob a ótica da justiça distributiva, visão predominante na doutrina e na jurisprudência brasileira. Consoante a este paradigma, a função social dos contratos tem como propósito equilibrar os poderes econômicos e fáticos entre as partes, ou seja, pretende alcançar a justiça social por meio dos contratos. Esclarecemos que a interpretação da função social dos contratos sob a ótica da justiça distributiva é proveniente do Estado Social, cujo objetivo primordial é a cooperação social. Em que pese o respeito a doutrinadores e juristas que adotam o paradigma da justiça distributiva, nossa posição é divergente, pois entendemos que o convite realizado ao judiciário para analisar a função social dos contratos tem como objetivo alcançar uma solução justa, harmonizando os interesses individuais e sociais contidos no pacto. Assim, nos parece temeroso o entendimento de que a funcionalização do contrato equivale sempre à proteção da parte mais frágil da relação do contrato, pois correríamos o risco de aniquilar a autonomia da vontade presente no momento da celebração do negócio jurídico.

Neste capítulo há uma divisão em dois tópicos: no primeiro, apresentamos noções teóricas e posições doutrinárias acerca do tema; já no segundo, discorremos sobre o entendimento jurisprudencial.

Como o intuito deste trabalho é apresentar a melhor compleição da expressão função social dos contratos contida no artigo 421 do Código Civil, cabe verifica-la pelo viés do STJ, pois é competência deste órgão uniformizar a interpretação de lei federal e garantir sua observância e aplicação. Assim, a análise dos julgados será realizada desde o seu estágio inicial - verificando o entendimento do Tribunal originário - até a decisão final prolatada pelo Superior Tribunal de Justiça.

Nesse contexto, o segundo capítulo irá analisar o caso emblemático denominado "Soja Verde", o qual demonstrou o efeito deletério da intervenção judicial nos contratos ao adotar o paradigma da justiça distributiva. Neste caso, a discussão se disseminou no Tribunal de Justiça de Goiás, o qual analisou inúmeros eventos semelhantes, tendo optado por revisar o contrato e privilegiar a parte mais frágil do pacto. Entendimento diverso foi o adotado pelo Superior Tribunal de Justiça ao utilizar o paradigma da eficiência econômica, cuja análise se dará no capítulo seguinte. 
Ainda neste capítulo, exploramos outro caso de grande relevo analisado pelo Tribunal de Justiça da Bahia, o qual compeliu os litigantes a manterem a relação contratual, pautando-se no ideal de justiça distributiva. Novamente, o caso repercutiu no Superior Tribunal de Justiça e reformou parcialmente a decisão.

O terceiro capítulo irá analisar a função social dos contratos sob a ótica da eficiência econômica. Salientamos que o presente paradigma é proveniente dos Estados Unidos, onde o movimento conhecido como "Law and Economics" analisa o ordenamento jurídico sob o espectro das teorias econômicas. Evidenciamos que este modelo privilegia a funcionalização do contrato, mas, também, procura preservar os interesses individuais. Assim, verifica-se que há uma preocupação em harmonizar os interesses individuais e sociais presentes no contrato em prol da preservação do espaço público de mercado.

Do mesmo modo que o capítulo anterior, realizaremos a abordagem em dois tópicos: no primeiro, apresentamos a visão teórica sobre o assunto e, no segundo, apresentamos a posição da jurisprudência. Nesse passo, iremos analisar os reflexos e a repercussão do caso da "Soja Verde" no Superior Tribunal de Justiça, o qual entendeu por bem reverter a decisão do Tribunal de origem em um raciocínio que se enquadra perfeitamente em nossa pesquisa.

Por fim, o quarto capítulo tratará da intervenção judicial nos contratos. O ponto fulcral deste trabalho é a interpretação da função social do contrato prevista no artigo 421 do atual Código Civil. Como podemos perceber, o referido instituto possui uma textura fluida, a qual estimula a atividade exegética do magistrado, assim, pretendemos demonstrar que a complementação da norma jurídica deve ser realizada com prudência e razoabilidade, atentando-se para os interesses das partes contratantes e para o delineamento realizado pelo legislador ao elaborar a norma. Nesse contexto, suscitamos o dever de cautela ao intérprete da norma, vez que, ao desbordar dos limites propostos pelo legislador, teremos evidente afronta ao princípio da separação dos poderes insculpido no artigo $2^{\circ}$ da Carta da República.

Sensível ao que foi exposto, podemos observar que o objetivo deste trabalho é apresentar os diferentes enfoques da função social dos contratos e a sua aplicação na jurisprudência, ressaltando que a identificação e a definição do sentido e do alcance do mencionado instituto devem ser realizadas com ponderação pelo Judiciário, visto os efeitos deletérios que 
o não cumprimento do contrato poderá acarretar ao espaço público de mercado. Portanto, é uma tentativa ainda rara de estudar a função social do contrato sob a perspectiva de um princípio favorável a atividade empresarial que nós sugerimos aqui.

\section{A CONCEPÇÃO DA FUNÇÃO SOCIAL DOS CONTRATOS NO CÓDIGO CIVIL DE 2002}

Reza o artigo 421 do Código Civil: "a liberdade de contratar será exercida em razão e nos limites da função social do contrato", assim, questiona-se qual seria o sentido e o alcance da expressão função social do contrato e em qual proporção a autonomia contratual será limitada.

Dada a relevância do referido instituto ao direito contratual, urge apresentar os diferentes olhares que sobre ele recaem. Nessa toada, o presente capítulo procura delinear os principais paradigmas conflitantes no que tange a função social do contrato, quais sejam: justiça distributiva $\mathrm{x}$ eficiência econômica.

Em síntese, o paradigma da justiça distributiva traduz a função social do contrato como instrumento protetivo da parte frágil da relação contratual; enquanto o paradigma da eficiência econômica adverte que o contrato como transação de mercado que é, deve resguardar os interesses individuais nele expressados, sem ignorar, contudo, os interesses coletivos dignos de proteção nas relações contratuais.

Ao tratar da inovação operada pelo Código Civil de 2002, Humberto Theodoro Júnior pondera:

Proclamou-se, em termos genéricos, o compromisso de todo o direito dos contratos com a ideologia constitucional de submeter a ordem econômica aos critérios sociais, mediante a harmonização da liberdade individual (autonomia da vontade) com os interesses da coletividade (função social). ${ }^{2}$

2 THEODORO JÚNIOR, Humberto - O contrato e sua função social - 4. ed. rev.atual. e amp. Rio de Janeiro: Forense, 2014, p. 41. 
Nesse contexto, temos que a função social do contrato substancia os seguintes princípios constitucionais: solidariedade (artigo $3^{\circ}$, inciso I, da $\mathrm{CF}$ ); função social da propriedade (artigo $5^{\circ}$, inciso XXIII e artigo 170 , inciso III, da CF); e livre iniciativa (artigo $1^{\circ}$, inciso IV, da CF).

Isto porque, o novo diploma civil busca efetivar os anseios de um Estado Democrático de Direito, o qual "assegura aos seus cidadãos o exercício efetivo não somente dos direitos civis e políticos, mas também e sobretudo dos direitos econômicos, sociais e culturais, sem os quais de nada valeria a solene proclamação daqueles direitos" ${ }^{3}$. Impõe-se concluir, deste modo, que o contrato tem que ser concebido não só pelo enfoque econômico, mas, também, atendendo a sua função social.

Nessa linha, cumpre registrar que a função econômica do contrato visa propiciar a circulação de bens e riquezas, por óbvio, temos que as partes contratantes possuem interesses diversos e divergentes, entretanto, "a persecução de interesses contrapostos não é empecilho para a construção de um ambiente contratual ético e compatível com a ordem jurídica" ${ }^{4}$.

Nessa nova contextualização, todavia, não se pode olvidar a função social do contrato, a qual pretende conciliar o interesse individual das partes contratantes com o interesse da coletividade, desta feita, representando uma fonte de equilíbrio social. Assim, a função social do contrato limita a liberdade contratual, vez que busca resguardar os interesses de terceiros estranhos ao vínculo negocial.

A este respeito, Nelson Nery Júnior esclarece:

O contrato tem de ser entendido não apenas como pretensões individuais dos contratantes, mas como verdadeiro instrumento de convívio social e de preservação dos interesses da coletividade. Interessa a toda a sociedade, na medida em que os standars contratuais são paradigmáticos para outras situações assemelhadas. Tudo que ocorre relativamente a um contrato

\footnotetext{
${ }^{3}$ MENDES, Gilmar Ferreira. Curso de direito constitucional/ Gilmar Ferreira Mendes, Inocêncio Mártires Coelho, Paulo Gustavo Gonet Branco. - 4 ed. rev. e atual. - São Paulo: Saraiva, 2009, p.171.

4 TEPEDINO, Gustavo; SCHREIBER, Anderson. Os efeitos da Constituição em relação à cláusula da boa-fé no Código de Defesa do Consumidor e no Código Civil. Revista da EMERJ, vol. 6, n 23, p. 148, 2003 apud THEODORO JÚNIOR, Humberto. O contrato e sua função social - 4.ed. rev. atual. e amp - Rio de Janeiro: Forense, 2014, p. 47.
} 
terá, forçosamente, repercussão em outros casos que digam respeito ao mesmo tipo de contrato. Essa é apenas uma das consequências da nova socialidade do contrato. Além de útil o contrato tem que ser justo. ${ }^{5}$

Insta mencionar que o artigo 421 do Código Civil constitui cláusula geral, ou seja, "formulação contida na lei, de caráter significativamente genérico e abstrato, cujos valores devem ser preenchidos pelo juiz, autorizado para assim agir em decorrência da formulação legal da própria cláusula geral" 6 . Em razão da abstração do instituto em tela, a responsabilidade pela identificação e definição de seu alcance ficará a cargo da doutrina e da jurisprudência.

Destarte, o que se pretende demonstrar são as possíveis interpretações da função social do contrato, inserida no artigo 421 do diploma civil, vez que qualquer equívoco cometido pelo magistrado será crucial para o ambiente de mercado.

Nesta linha, manifesta-se Rachel Sztajn:

Por outro lado, uma interpretação errônea pode levar ao entendimento de que os contratos devem submeterse a algum outro desígnio extracontratual, qual seja denominado "social". Neste caso, o artigo é extremamente danoso, e poderá causar uma generalizada desconfiança nos procedimentos contratuais, com os consequentes problemas daí decorrentes. Dessa forma, a interpretação deste artigo pode dar margem a um grave problema de eficiência econômica, podendo levar até mesmo a um questionamento da propriedade privada. $^{7}$

Neste contexto, o juiz terá a árdua tarefa de perquirir os valores jurídicos, sociais e econômicos do contrato a fim de concretizar a cláusula geral em comento. No entanto, a atuação do magistrado deve ser permeada com a devida cautela, pois apesar da cláusula geral estimular a atividade

\footnotetext{
${ }^{5}$ NERY JÚNIOR, Nelson. Código Civil Comentado/ Nelson Nery Junior, Rosa Maria de Andrade Nery - 7.ed. ver. ampl. atual. até 25.8.2009. São Paulo: Editora Revista dos Tribunais, 2009, p. 531. ${ }^{6}$ GONÇALVES, Carlos Roberto. Direito Civil Brasileiro. Direito Civil Brasileiro, volume III: contratos e atos unilaterais / Carlos Roberto Gonçalves. - São Paulo: Saraiva, 2004. p. 7

${ }^{7}$ SZTAJN, Rachel. Revista de Direito Mercantil, Industrial, Econômico e Financeiro. Nova Série, Ano XLIV, n.139-julho-setembro de 2005. São Paulo: Editora Malheiros, p.47.
} 
jurisdicional, esta não poderá concretizar os valores pessoais do julgador, sob pena de substituir a sua própria vontade pela vontade das partes contratantes. Assim, o preenchimento das cláusulas abertas deve ser realizado de maneira responsável para que as decisões não tenham apenas aparência racional, mas que, efetivamente, atendam à função de socialidade do contrato.

Neste sentido, Jose Luis de Los Mozos se manifesta:

Com efeito, não se considera permita a cláusula geral, se admitido o reenvio a critérios metajurídicos, deles se valha o julgador para subjetivar, de modo absoluto, seu ato decisional. Em outras palavras, diante de uma cláusula geral não se permite ao aplicador apenas justificar a criação da regra do caso concreto pelo que ele considera justo, a pretexto de que a tanto autorizado pelo reenvio a critérios extrajurídicos, puramente ético ou morais, como se eles se desenvolvessem à margem do direito. ${ }^{8}$

Sensível à noção acima exposta, urge ressaltar que a complementação da norma jurídica pelo magistrado não pode desconstituir o sentido pretendido pelo legislador ao editar o dispositivo civil da função social dos contratos, caso contrário, constituiria uma ofensa à separação dos poderes, constante no artigo $2^{\circ}$, da Constituição Federal. Neste sentido, "Montesquieu chegou a dizer que não existiria liberdade política onde se misturassem funções próprias de cada órgão da soberania estatal" ${ }^{9}$. Em que pese a fluidez da referida cláusula, o legislador, ao editar o artigo 421 do Código Civil, conformou o valor de socialidade ao contrato, o qual deve ser entendido como valores de solidariedade e justiça social; livre iniciativa; dignidade da pessoa humana.

\footnotetext{
${ }^{8}$ LOS MOZOS, Jose Luis de. Metodologia y ciência em el derecho privado moderno. Madrid: Rev. de Derecho Privado, 1977, p. 323 citado e traduzido por GODOY, Cláudio Luiz Bueno de. Tese de Doutorado apresentada à PUC-SP, sob orientação do Professor Doutor Renan Lotufo, p. 145.

${ }^{9}$ Montesquieu. Do espírito das leis, São Paulo: Difusão Européia do Livro, 1962, v.1, p. 181 apud MENDES, Gilmar Ferreira. Curso de direito constitucional/ Gilmar Ferreira Mendes, Inocêncio Mártires Coelho, Paulo Gustavo Gonet Branco. - 4 ed. rev. e atual. - São Paulo: Saraiva, 2009. p.115.
} 
Imperioso mencionar que a doutrina e a jurisprudência, ao procederem à concretização da cláusula geral da função social, o fazem sob dois enfoques: justiça distributiva e eficiência econômica.

Dentro do ângulo da justiça distributiva, a função social dos contratos é tida como a proteção da parte mais fraca da relação contratual, pretendendo realizar a justiça social por meio do contrato. Por vezes, a pretexto da aplicação da função social dos contratos, o judiciário redistribui de maneira arbitrária os benefícios econômicos auferidos no contrato, deste modo, desrespeitando o preceito da autonomia privada. Entretanto, nem sempre o interesse coletivo será a tradução do interesse da parte mais fraca, portanto, nítidos os efeitos deletérios que a intervenção judicial irá acarretar ao espaço público de mercado.

Nas palavras de Humberto Theodoro Júnior:

Dessa maneira, afirmar que o contrato tem a função de promover a igualdade dos contratantes equivale a dizer que esse tipo de negócio tem como objetivo fazer com que as partes 'sejam iguais'. Ora, o contrato jamais terá semelhante objetivo porque não se trata de instrumento de assistência ou de amparo a hipossuficientes ou desvalidos (...). Daí a imprestabilidade da tese de que o contrato teria a função social de igualar os contratantes. Somente sendo diferentes e exercendo interesses opostos, as pessoas praticarão o contrato, como instrumento naturalmente destinado à função específica de realizar a circulação dos bens patrimoniais entre pessoas diferentes e que atuam com objetivos distintos no relacionamento jurídico estabelecido. ${ }^{10}$

Na perspectiva da eficiência econômica, não se ignora a relevância do interesse social na relação contratual, entretanto, distingue o interesse coletivo e a proteção da parte mais fraca, visando resguardar as relações de mercado que são estruturadas nas expectativas dos agentes econômicos. Nessa linha, Luciano Benetti Timm salienta:

Os bens e serviços deverão circular de acordo com a vontade das partes, expressa nos contratos, sendo

10 THEODORO JÚNIOR, Humberto. O contrato e sua função social - 4. ed. rev. atual. e amp - Rio de Janeiro: Forense, 2014, p. 47-48. 
direcionados à parte que mais os valorize. Uma vez que os indivíduos possuem interesses distintos e sejam suficientemente racionais para estabelecer uma escala de preferenciais, estarão, assim, aptos a maximizar a sua utilidade no processo de transação. Isso gerará riqueza na sociedade. ${ }^{11}$

Sensível a tudo quanto foi exposto, o que se pretende é demonstrar a relevância jurídica da função social do contrato, visando ressaltar prudência e razoabilidade que deverão emanar das manifestações do Judiciário ao buscar viabilizar a cláusula aberta contida no artigo 421 do Código Civil. Nessa linha, mister salientar as ponderações realizadas por Arnoldo Wald:

Deve-se, entretanto, ponderar que a função social do contrato não deve afastar a sua função individual, cabendo conciliar os interesses das partes e da sociedade. Assim, os direitos contratuais, embora exercendo uma função social, constituem direitos adquiridos (art. $5^{\circ}$, XXXVI) e gozam, nos termos da Constituição, do devido processo legal substantivo (art. $5^{\circ}$, LIV), em virtude do qual ninguém pode ser privado dos seus bens - e dos seus direitos, que também se incluem entre os bens - sem o devido processo legal. Com essa interpretação que é a única aceitável em nosso regime constitucional, a inovação do Código de 2002 não põe em risco a sobrevivência do contrato, como manifestação da vontade individual e acordo entre partes interessadas para alcançar determinado objetivo, por elas definido em todos os seus aspectos. 12

Compadecendo do ensinamento acima esposado, a interpretação da cláusula geral, contida no artigo 421 do diploma civil, atenderá aos anseios do legislador constitucional, contanto que proceda com ponderação e razoabilidade entre interesses individuais e coletivos inerentes ao contrato

11 TIMM, Luciano Benetti. Função Social do Direito Contratual no Código Civil Brasileiro: Justiça Distributiva VS. Eficiência Econômica.

12 WALD, Arnaldo. Direito Civil: direito das obrigações e teoria geral dos contratos, 2/ Arnaldo Wald; com a colaboração dos professores Seny Glanz, Ana Elizabeth Lapa Wanderley Cavalcanti e Liliana Mirandi Paesani. - 21. ed. - São Paulo: Saraiva, 2013, p. 248. 
para que, deste modo, prestigie os valores constitucionais de socialidade sem, no entanto, aniquilar os demais valores que orientam o ordenamento jurídico, como a autonomia da vontade.

\section{A FUNÇÃO SOCIAL DOS CONTRATOS SOB A ÓTICA DA JUSTIÇA DISTRIBUTIVA}

\subsection{O PARADIGMA DA JUSTIÇA DISTRIBUTIVA}

A função social dos contratos é proclamada por parte significativa da doutrina ${ }^{13}$ como expressão da justiça distributiva, neste sentido, a cláusula aberta contida no artigo 421 do atual Código Civil realizará, no âmbito contratual, justiça social proveniente do Estado Social.

O Código Civil de 2002 apresenta-se como estatuto comprometido com a diretriz constitucional da solidariedade social, deste modo, a sobreposição do interesse coletivo em face do interesse individual seria

\footnotetext{
13 Neste sentido, Luciano Benetti Timm aponta inúmeros doutrinadores adeptos desta visão: WALD, Arnoldo. O novo Código Civil e o solidarismo contratual. Revista de Direito Bancário, do Mercado de Capitais e da Arbitragem 21/35. São Paulo: Revista dos Tribunais, jul.-set. 2003; NERY, Rosa Maria Andrade. Apontamentos sobre o princípio da solidariedade no sistema do direito privado. Revista de Direito Privado 17/70. São Paulo: Revista dos Tribunais, jan.-mar. 2004; SILVA, Jorge Cesa Ferreira da. Princípios de direito das obrigações no novo Código Civil. In: SARLET, Ingo (Org.). O novo Código Civil e a Constituição. Porto Alegre: Livraria do Advogado, 2003, p. 99; PENTEADO JR., Cássio M. C. O relativismo da autonomia da vontade e a intervenção estatal nos contratos. Revista de Direito Bancário, do Mercado de Capitais e da Arbitragem, v. 21. São Paulo: Revista dos Tribunais, jul.-set. 2003, p. 211; GOGLIANO, Daisy. A função social do contrato (causa ou motivo). Revista Jurídica, n. 334, ago. 2005, p. 9; MARTINS-COSTA, Judith. Reflexões sobre o princípio da função social dos contratos. Revista DireitoGV, v. 1, São Paulo: Fundação Getulio Vargas, 2005, p. 41; PACHECO, José da Silva. Da função social do contrato. Revista Advocacia Dinâmica, 34, 2003, p. 496; SANTOS, Eduardo Sens. A função social do contrato - elementos para uma conceituação. Revista de Direito Privado 13/99. São Paulo: Revista dos Tribunais, jan.-mar. 2003; WAMBIER, Teresa Arruda Alvim. Uma reflexão sobre as cláusulas gerais do Código Civil de 2002 - a função social do contrato. RT 831/59. São Paulo: Revista dos Tribunais, 2005, p. 59; THEODORO DE MELLO, Adriana Mandim. A função social do contrato e o princípio da boa-fé no novo Código Civil brasileiro. RT 801/11. São Paulo: Revista dos Tribunais, jul. 2002, dentre outros. (Fonte: TIMM, Luciano Betti. Função Social do Direito Contratual no Código Civil Brasileiro: Justiça Distributiva VS. Eficiência Econômica. RIDB, Ano 1 (2012). No. 6 .
} 
plenamente justificável, visto o entendimento destes doutrinadores acerca da função social dos contratos.

Nesta linha de intelecção, a expressão função social se equipara a tutela do hipossuficiente na relação contratual, sob o argumento de que o escopo do Estado Democrático de Direito é resguardar os direitos sociais, assim, para esta parcela da doutrina, nada mais coerente do que a aplicação de justiça social por meio dos contratos.

Nesta linha, cumpre registrar as palavras de Dirley da Cunha Júnior sobre a ideia de justiça social advinda do Estado Social:

Direitos sociais como condições de implementação do objeto primário da justiça social que é, na teoria de Rawls, a estrutura básica da sociedade, ou seja, a maneira pela qual as instituições sociais mais importantes distribuem direitos e deveres e determinam a divisão de vantagens provenientes da cooperação social. E uma justiça social depende fundamentalmente de como se atribuem direitos e encargos das oportunidades econômicas e condições sociais que existem nos vários setores da sociedade. ${ }^{14}$ (grifo nosso).

Sob a égide do direito privado constitucionalizado, os adeptos da função social dos contratos como instrumento de aplicação da justiça distributiva veem o referido instituto como uma ferramenta de proteção da parte mais fraca da relação contratual.

Nesta perspectiva, o interesse social revela o interesse da parte mais frágil da relação negocial, pois, muitas vezes, a manifestação de vontade dessa parte não é emanada livremente, visto o poder de barganha da parte contrária, economicamente mais forte.

Compartilhando deste entendimento, Augusto Geraldo Teizen Júnior propõe o seguinte conceito para a função social do contrato: "a finalidade pela qual visa o ordenamento jurídico a conferir aos contratantes medidas ou mecanismos jurídicos capazes de coibir qualquer desigualdade

\footnotetext{
${ }^{14}$ CUNHA JÚNIOR, Dirley. Curso de Direito Constitucional. 4. ed. rev., atual. Bahia: Jus Podivm. 2010. p. 589.
} 
dentro da relação contratual" ${ }^{15}$. Para arrematar, o autor realiza as seguintes ponderações:

Em síntese, a força obrigatória do contrato, que tinha na vontade dos contratantes seu fundamento primordial, se 'funcionaliza' quando a liberdade de contratar deva ser exercida em razão e nos limites da função social do contrato, ou seja, o vínculo jurídico reconhecido à vontade individual não é mais derivado do acordo das partes contratantes, mas, sim, da própria lei, cujos fins albergados pelo direito são a justiça social, a segurança, o bem comum, a dignidade da pessoa humana. ${ }^{16}$

Nesse mesmo sentido, as palavras de Judith Martins-Costa esclarecem:

O princípio da função social, ora acolhido expressamente no Código Civil, constitui, em termos gerais, a expressão da socialidade no Direito Privado, projetando em seus corpos normativos e nas distintas disciplinas jurídicas a diretriz da solidariedade social (CF, art. $3^{\circ}$, III, in fine). (...) o princípio da função social indica um caminho a seguir, oposto ao do individualismo predatório. ${ }^{17}$

Nesta acepção, o legislador, ao elaborar o dispositivo 421 do Código Civil, convida o intérprete a realizar uma releitura dos princípios contratuais, para que, deste modo, o contrato transcenda os interesses individuais das partes contratantes. Por corolário, o que se pretende é a atenuação da autonomia privada e da força obrigatória dos contratos, uma vez que a sua função social limita a liberdade de contratar.

15 TEIZEN JÚNIOR, Augusto Geraldo. A função social no Código Civil, p.166 apud BERALDO, Leonardo de Faria. Função Social do Contrato: Contributo para a Construção de uma Nova Teoria. Belo Horizonte: Del Rey, 2011, p. 81.

16 TEIZEN JÚNIOR, Augusto Geraldo. A função social no Código Civil, p.167 apud BERALDO, Leonardo de Faria. Função Social do Contrato: Contributo para a Construção de uma Nova Teoria. Belo Horizonte: Del Rey, 2011, p. 81

${ }^{17}$ MARTINS-COSTA, Judith. Reflexões sobre o princípio da função social dos contratos. Revista Direito GV, v.1.n.1, 2005, p. 41-66. Disponível em: <http://bibliotecadigital.fgv.br/ojs/index.php/revdireitogv/article/view/35261>. Acesso em: 14. Dez.2014. 
Rejeita-se, desta maneira, aquela visão individualista que permeou o Estado Liberal no século XIX, o qual repelia a presença do Estado no domínio privado. Até mesmo porque as inúmeras transformações inseridas nas estruturas política e econômica da sociedade clamavam por uma intervenção estatal a fim de solucionar os problemas então instalados.

Neste passo, insta mencionar que a atual Constituição Federal preconiza, em seu preâmbulo, a instituição de um "Estado Democrático de Direito, destinado a assegurar o exercício dos direitos sociais e individuais, a liberdade, a segurança, o bem-estar, o desenvolvimento, a igualdade e a justiça como valores supremos de uma sociedade fraterna, pluralista e sem preconceitos, fundada na harmonia social e comprometida, na ordem interna e internacional, com a solução pacífica das controvérsias".

Assim, atentos ao fenômeno da publicização do direito privado, os adeptos da função social como instrumento da justiça distributiva enxergam certos princípios contratuais como individualistas e desconexos com os preceitos constitucionais acima explicitados. Neste sentido, Teresa Negreiros leciona:

Nesta sua acepção, o princípio da função social encontra fundamento constitucional no princípio da solidariedade, a exigir que os contratantes e os terceiros colaborem entre si, respeitando as situações jurídicas anteriormente constituídas, ainda que as mesmas não sejam providas de eficácia real, mas desde que a sua prévia existência seja conhecida pelas pessoas implicadas. (...) Essa ótica individualista e voluntarista deve ser superada diante do sentido se solidariedade presente no sistema constitucional. (...) Novas doutrinas vêm reformulando o princípio da relatividade em vista do declínio de seu substrato, qual seja: a autonomia da vontade como fundamento da força obrigatória do contrato. ${ }^{18}$

Há que se ressaltar, ainda, as palavras de Luciano Benetti Timm acerca deste tema:

Nesse modelo paternalista, portanto, a função social do contrato significaria promover a solidariedade, i.e.

\footnotetext{
${ }^{18}$ NEGREIROS, Teresa. Teoria do contrato: novos paradigmas. $2^{\mathrm{a}}$ ed. Rio de Janeiro: Renovar, 2006. p.209 - p.2012.
} 
corrigir o desequilíbrio de poder no espaço do contrato e distribuir o resultado econômico do relacionamento entre as partes, que não lograra êxito através da livre barganha, processo em que a parte mais fraca sucumbe diante do mais forte (justiça social). ${ }^{19}$

Impõe-se concluir que a função social sob a ótica da justiça distributiva é, em verdade, a proteção da parte mais frágil da relação contratual, vez que pressupõe fictícia a liberdade de contratar diante da disparidade do poder de barganha entre as partes. Para os defensores desta corrente, o juiz, ao preencher a cláusula fluida da função social do contrato, deverá se ater à noção de realizar a justiça social por meio do contrato.

Assim, a cláusula aberta consignada no artigo 421 do Código Civil irá estimular a atividade exegética do magistrado que deverá buscar o exato sentido pretendido pelo legislador ao delinear a função social dos contratos.

Entretanto, o que se pretende esclarecer neste trabalho é a cautela com a qual o intérprete deve proceder ao pretender alcançar o preenchimento do mencionado instituto, pois, contíguo aos valores constitucionais de socialidade, devem estar os interesses individuais das partes contratantes manifestadas no momento da celebração do contrato, sob pena de ferir a própria acepção do instituto "contrato".

José de Oliveira Ascensão salienta: "o exercício das cláusulas gerais não se pode transformar numa esgrima de conceitos indefinidos ou num apelo a emoção. Deve ser aprofundado e racionalizado, porque só assim permite atingir a justiça sem pôr em causa a segurança" 20 .

Em outras palavras, o que se almeja é funcionalizar o contrato atendendo os preceitos constitucionais, do mesmo modo, resguardando os interesses individuais proferidos pelas partes no momento da celebração do pacto. Caso contrário, estaríamos admitindo a redação de um novo contrato observando os anseios exclusivos da parte mais fraca da relação ou até mesmo os valores pessoais do juiz, desvirtuando o instituto "contrato", o

19 TIMM, Luciano Benetti. Função Social do Direito Contratual no Código Civil Brasileiro: Justiça Distributiva VS. Eficiência Econômica. RIDB, Ano 1 (2012). Nº 6.

${ }^{20}$ ASCENSÃO, José de Oliveira. O projeto do novo Código Civil. São Paulo: Saraiva, 1999, 83. Apud THEODORO JÚNIOR, Humberto. O contrato e sua função social 4.ed.rev.atual. e amp. Rio de Janeiro: Forense, 2014, p. 138-139. 
qual traduz o "acordo de vontades para o fim de adquirir, resguardar, modificar ou extinguir direitos" 21.

\subsection{ANÁLISE JURISPRUDENCIAL ACERCA DO PARADIGMA DA JUSTIÇA DISTRIBUTIVA}

Releva notar alguns julgados que utilizaram a função social do contrato como instrumento de justiça social. Neste ponto, a funcionalidade do contrato serviu para ditar uma nova concepção de interesse social, a qual se confunde com o interesse da parte mais fraca da relação negocial.

Em estudo, Luciano Benetti Timm ${ }^{22}$ menciona o caso emblemático da "Soja Verde", o qual demonstrou o grandioso efeito deletério da intervenção judicial nos contratos, segundo pesquisa conduzida pelo Instituto Pensa USP.

Em síntese, o caso se apresentou da seguinte maneira: a produção de soja no Estado de Goiás era realizada através de capital privado, desta forma, os negociadores compravam o produto de maneira antecipada, logo, o recebimento deste capital pelos agricultores viabilizava o plantio. No entanto, houve um período em que a soja se valorizou de maneira inesperada, razão pela qual os agricultores ingressaram na justiça para obstar a entrega do produto aos negociadores. Frise-se que, na ocasião, estes haviam pagado antecipadamente pela produção.

O Tribunal de Justiça de Goiás revisou o contrato com base em sua função social, liberando os agricultores de entregar a soja aos negociadores. Â guisa de exemplificação, a Apelação Cível 91.921-2/188 e a Apelação Cível 79.859-2/188, embora julgadas por Câmaras distintas, convergem ao determinar ferido o princípio da equivalência contratual bem como

\footnotetext{
${ }^{21}$ BEVILAQUA, Clóvis. Código Civil dos Estados Unidos do Brasil, v. IV, obs. 1 ao art. 1.079. apud GONÇALVES, Carlos Roberto. Direito Civil Brasileiro: contratos e atos unilaterais. São Paulo: Saraiva, 2004, p. 2.

${ }^{22}$ Seminário Instituto Pensa realizado na USP em 05.12.2005 apud TIMM, Luciano Benetti. Direito, Economia e a função social do contrato: em busca dos verdadeiros interesses coletivos protegíveis no mercado de crédito. Disponível em: http://www.tex.pro.br/home/artigos/78-artigos-abr-2007/5581-direito-economia-e-a-funcao-social-do-contrato-embusca-dos-verdadeiros-interesses-coletivos-protegiveis-no-mercado-do-credito. Acesso em: 30 dez. 2014.
} 
o princípio da função social dos contratos, acarretando na revisão dos contratos.

Não obstante favorável aos agricultores, impossível não perceber que as decisões foram prejudiciais para o mercado em questão, pois, nos anos seguintes, verificou-se uma redução no financiamento no plantio da soja diante da insegurança e descrença dos negociadores no cumprimento do contrato pela outra parte.

Neste passo, cumpre transcrever a ementa dos julgados supramencionados em que o Tribunal de Justiça de Goiás revisou o contrato em prol dos agricultores, parte mais frágil da relação negocial, sob o argumento de conferir aplicabilidade ao princípio da função social do contrato:

Ação de nulidade de contrato de compra e venda de soja. Cerceamento de defesa. Julgamento antecipado. Princípio da equivalência contratual. Alegação de desequilíbrio contratual. Revisão. Possibilidade. I - Não há falar no cerceamento do direito de defesa em face do julgamento antecipado da lide, quando as provas inclusas aos autos são suficientes para o convencimento do julgador. II - - Ferido o princípio da equivalência contratual, sobretudo no que tange à boa-fé objetiva, face as desproporções das obrigações, face o contrato estipular deveres tão-só ao vendedor (produtor rural), tal circunstância importa resolução do pacto, ao teor do art. 478 do CC, por estar vislumbrada a onerosidade excessiva impingida a uma das partes. III - - O princípio do pacta sunt servanda encontra-se abrandado com a vigência do Código Civil de 2002, que sedimentou o posicionamento, frente aos princípios erigidos pela nova teoria contratual, dos quais destacam-se: da função social do contrato, da boa-fé e do equilíbrio econômico (arts. 421, 422, parágrafo único do art. 2.036). IV - - A teoria da imprevisão vem socorrer justamente esta situação, pois determina adequação do contrato à realidade fática, principalmente para restabelecer $o$ equilíbrio do pacto, quando ocorrer fato superveniente, extraordinário e imprevisível, que interfere substancialmente na sua efetivação e produz grande prejuízo para uma das partes. V - - Cabe ao Judiciário repelir as práticas abusivas do mercado para coibir 
principalmente o lucro excessivo de um em detrimento do prejuízo de outrem, revisando ou declarando nulas as cláusulas contratuais que ocasionem um desequilíbrio flagrante entre os contratantes. Apelo conhecido e improvido. Sentença confirmada. $^{23}$

Apelação cível. Ação de rescisão contratual. Compra e venda de soja. Função social do contrato. Lesão enorme. Onerosidade excessiva. Ofensa ao princípio da boa-fé objetiva e da equivalência contratual. Rescisão. Possibilidade. Nos contratos de execução continuada ou diferida, o desatendimento da função social do contrato e a ofensa aos princípios da boa-fé objetiva e da equivalência contratual faz exsurgir para a parte lesionada o direito de rescindir o contrato, mormente se ocorrerem acontecimentos extraordinários e imprevisíveis que tornem excessivamente oneroso o cumprimento da prestação a que se obrigará. Exegese dos arts. 421, 422 e 478, todos da Lei 10.406/2002, novo Código Civil brasileiro. Apelação conhecida e improvida. ${ }^{24}$

Nesta diretriz, o estudo realizado pelo Instituto Pensa - USP detectou que os julgados do Tribunal de Justiça de Goiás convergiram para determinar que a funcionalidade do contrato não havia sido respeitada, deste modo, revisaram-no a fim de liberar os agricultores a entregar o produto. Por conseguinte, constatou-se enorme abalo ocasionando no sistema agroindustrial de financiamento de soja, visto a redução no volume de contratos realizados nas safras posteriores.

Imperioso elucidar que o financiamento de soja realizado pelo Governo não era suficiente para suprir a necessidade dos agricultores em realizar o plantio do produto, visto sua insuficiência de recursos. Em face desta situação, o contrato de compra e venda antecipado de soja apresentou-se como alternativa para obtenção de crédito por parte dos agricultores. Nota-se, assim, a importância dos negociadores para a produção dos grãos de soja e o correto emprego do princípio que ora estudamos, pois, a sua

\footnotetext{
${ }^{23}$ Apelação Cível 91.921-2/188, $3^{\text {a }}$ Câmara Cível, TJ-GO

${ }^{24}$ Apelação Cível 79.859-2/188, $1^{\text {a }}$ Câmara Cível, TJ-GO.
} 
utilização equivocada implicou em um resultado inverso ao interesse social neste caso.

No que diz respeito aos contratos denominados "Soja Verde", Christiane Leles Rezende, com arrimo em Jank, obtempera:

Com uma operação desta natureza, o produtor elimina os riscos de preço e garante, já no plantio, sua margem de lucro e transfere para o mercado boa parte dos riscos do negócio. Assim, além de financiar a produção, esse sistema dilui entre os agentes os riscos intrínsecos da soja. ${ }^{25}$

A autora prossegue afirmando que, ao realizar os contratos de "Soja Verde", "sob a ótica econômica, pode-se dizer que pelo menos dois elementos podem estar sendo transacionados: risco e/ou crédito".

Por óbvio que os riscos são inerentes aos contratos de compra e venda antecipada de soja, desta feita, compete ao Judiciário sanar eventuais desequilíbrios contratuais, todavia, deve observar e amparar as expectativas dos agentes econômicos.

Neste sentido, Luciano B. Timm ressalta o "importante papel institucional e social que o direito contratual pode oferecer em um regime de mercado" 26 .

Conclui-se, deste modo, que a atividade exegética do artigo 421 do Código Civil deve ser permeada com a devida cautela, sob pena de conspurcar o objetivo do legislador ao redigir a referida cláusula aberta e, em longo prazo, acaba por ter um efeito inverso ao seu objetivo primeiro.

No presente caso, evidenciaram-se os efeitos danosos ocasionados ao espaço público de mercado ao interpretar a funcionalidade do contrato como o interesse da parte mais frágil da relação contratual, vez que as decisões proferidas pelo Tribunal de Justiça de Goiás se preocuparam, tão

\footnotetext{
25 REZENDE, Christiane Leles. Pacta Sunt Servanda? Quebra dos Contratos de Soja Verde. Tese de Doutorado apresentada a Faculdade de Economia Administração e Contabilidade da Universidade de São Paulo defendida em 15.02.2008. Disponível em: http://www.teses.usp.br/teses/disponiveis/12/12139/tde-07042008-143732/pt-br.php.

${ }^{26}$ TIMM, Luciano Benetti. Direito, economia e a função social do contrato: em busca dos verdadeiros interesses coletivos protegíveis no mercado de crédito. Disponível em: http://www.tex.pro.br/home/artigos/78-artigos-abr-2007/5581-direito-economia-e-a-funcao-social-do-contrato-em-busca-dos-verdadeiros-interesses-coletivos-protegiveis-nomercado-do-credito. Acesso em 30.12.2014.
} 
somente, com o interesse das partes litigantes, ou seja, ignorou os possíveis efeitos que a sentença poderia acarretar ao mercado em geral. Isto resultou na redução de volume de contrato de compra e venda antecipada de soja nas safras posteriores. De certa forma, é possível afirmar que falta a esse tipo de decisão uma visão não apenas micro, mas, sobretudo, macroeconômica.

Assim, temos que o interesse social deve ser observado de maneira ampla, ou seja, atentando-se ao interesse de todos os agentes envolvidos, não só na relação presente, mas, também, nas relações futuras. A ideia de uma função social do negócio jurídico não pode se tornar em um princípio de função puramente tutelar do hipossuficiente, como remédio paliativo e temporário, sem um planejamento econômico mais estrutural.

Nessa toada, acreditamos que o posicionamento de alguns doutrinadores como Giselda Hironaka, para a qual a função social do contrato é uma "técnica destinada a traduzir melhor a proteção dos interesses do contratante economicamente fraco, restringindo-se a liberdade contratual do contratante economicamente forte, especialmente no que se refere ao conteúdo do negócio" ${ }^{27}$ mostra-se arriscada.

Em outro caso, o Tribunal de Justiça da Bahia valeu-se da função social do contrato, pautada no ideal de justiça social/distributiva, para compelir as litigantes a manterem forçosamente a relação contratual existente. Todavia, atento aos efeitos danosos que a funcionalização do contrato à luz da justiça social poderia acarretar ao ordenamento jurídico e à segurança jurídica, o Superior Tribunal de Justiça entendeu por bem reformar, parcialmente, a decisão proferida pelo Tribunal de Justiça da Bahia.

De forma mais detalhada, trata-se de ação cautelar interposta pela CT Brasil Ltda. em face da Companhia de Eletricidade do Estado da Bahia (Coelba), em que a recorrente afirma ter prestado serviços em sistemas elétricos à recorrida, durante cinco anos, atuando de maneira quase que exclusiva. Nesse passo, a recorrente acusa a recorrida de abusar de seu poderio econômico para rescindir unilateralmente a parceria existente, o que lhe ocasionaria prejuízos irrecuperáveis. Assim, a recorrente ajuizou a presente ação pretendendo a manutenção do contrato. A decisão $a$ quo corroborou a decisão liminar, julgando procedente o pleito autoral e constrangendo as partes a manterem a relação contratual, sob pena de multa diária.

\footnotetext{
${ }^{27}$ HIRONAKA, Giselda apud BERALDO, Leonardo de Faria. Função Social do Contrato: Contributo para a Construção de uma Nova Teoria. Belo Horizonte: Del Rey, 2011, p. 80.
} 
Inconformada com a decisão a quo, a recorrida, a Coelba interpôs recurso de apelação, todavia, o TJ-BA negou-lhe seguimento nos seguintes termos:

Apelação cível. Ação cautelar inominada. Rescisão unilateral e injustificada de contratos. Inadmissibilidade. Afronta à função social. Violação do princípio da preservação da empresa. Julgamento antecipado da lide. Sentença adstrita aos limites do pedido. Fundamento suficiente. Multa por descumprimento. Inteligência dos arts. $461, \S 4^{\circ}$, e 464 do CPC. Preliminares rejeitadas. Improvimento do apelo. O julgamento antecipado da lide, quando a questão proposta é exclusivamente de direto não viola o princípio constitucional da ampla defesa e do contraditório. Não há que se falar em perda superveniente do objeto de ação cautelar inominada que busca o cumprimento de contratos expirados no curso do processo, uma vez que ação principal discutirá eventuais indenizações decorrentes da rescisão unilateral. A rescisão unilateral dos instrumentos viola a função social do contrato, compreendo-a com a finalidade pela qual o ordenamento jurídico confere aos contratantes mecanismos jurídicos capazes de coibir qualquer desigualdade dentro da relação contratual. O Novo Código Civil Brasileiro, ao estabelecer em seu art. 421 que a liberdade de contratar será exercida em razão e nos limites da função social do contrato, apenas normatizou entendimento que já se encontrava consolidado na doutrina e na jurisprudência pátrias. A simples alegação de cumprimento da media, desprovida de demonstração satisfativa, não autoriza modificação da parte dispositiva de sentença, que se louvou na norma inserta no $\$ 40$, do art. $461 \mathrm{c}$ art. 64, do CPC, que faculta ao julgador a imposição de multa diária, com o fito de assegurar a execução de obrigação de fazer. ${ }^{28}$ (grifo nosso).

Evidencia-se da decisão supratranscrita, a adoção da visão paternalista ao aplicar a função social do contrato como mecanismo jurídico

${ }^{28}$ Retirada do STJ, RESP 972.436 - BA (2007/0179867-7), 3T, Min. Relatora NANCY ANDRIGHI, DJe 12.06.2009. 
capaz de extirpar as desigualdades advindas da relação contratual. Segundo esta corrente doutrinária, a publicização do direito privado implica em uma remodelagem da teoria geral dos contratos, na qual o plano individual restará abrandado diante de valores plurais, deste modo, humanizando o direito contratual.

Compartilha deste entendimento o desembargador Jones Figueirêdo Alves: "o contrato não é apenas um instrumento jurídico, de interesses puramente interpessoais ou de operação de proveitos. O seu conteúdo deve importar nos fins de justiça e de utilidade, em superação do egocentrismo individual onde permeiam a fragilização do débil e a dominação do mais forte" 29 . Firme em tais lineamentos, o TJ-BA decidiu manter forçosamente a relação contratual existente entre CTC e Coelba nutrido pelos influxos sociológicos oriundos da atual Magna Carta, deste modo, interpretando a funcionalização do contrato como instrumento de igualdade em favor da correção do negócio.

Entretanto, o que se denota da referida decisão é a distorção do negócio jurídico, não sua correção. Em que pese a respeitável percepção paternalista e distributiva da função social dos contratos, compelir as partes contratantes a manter relação não mais desejada afronta à própria ideia de "Contrato", em que se supõe uma regulação consensual de interesses.

Na ponderação do Enunciado 23 do $\mathrm{CFJ} / \mathrm{STJ}^{30}$, a função social do contrato, cláusula aberta prevista no artigo 421 da legislação civil, não elimina o princípio da autonomia da vontade, apenas o atenua à vista de interesses plurais. No entanto, a decisão prolatada pelo TJ-BA acabou por extirpar a autonomia da vontade das partes contratantes ao obrigar a permanência indesejada da relação negocial.

O jurista italiano Emilio Betti ressalta a importância de conciliarmos o interesse socialmente apreciável e a autonomia privada, inerente aos contratos. Para compreender a correta noção de autonomia privada preconizada pelo ilustre professor, citemos o seguinte trecho de sua lição:

\footnotetext{
${ }^{29}$ ALVES, Jones Figueirêdo. Código Civil Comentado/ coordenadora Regina Beatriz Tavares da Silva. 9.ed. de acordo com a Lei n. 12.607/2012 e ADF 132 e ADI 4.277. São Paulo: Saraiva, 2013, p.423.

${ }^{30}$ Enunciado 23 do CFJ/STJ: Art. 421: a função social do contrato, prevista no art. 421 do novo Código Civil, não elimina o princípio da autonomia contratual, mas atenua ou reduz o alcance desse princípio quando presentes interesses meta individuais ou interesse individual relativo à dignidade da pessoa humana.
} 
E nessa investigação é necessário utilizar, especialmente no ambiente da sociedade moderna, um grau de sensibilidade social, de que o velho individualismo dos juristas não tinha a menor ideia. Só assim, examinada a estrutura - forma e conteúdo (o como e o quê) - do negócio, pode resultar frutuoso estudar-lhe a função (o por quê). Essa função, que em terminologia técnica, legitimada pela tradição, se denomina a "causa", ou seja, a razão do negócio, liga-se, logicamente, àquilo que é o conteúdo do negócio, sem, no entanto, se identificar com ele. Conteúdo do negócio é - como dissemos - não uma vontade qualquer, expressão vazia e incolor do capricho individual, mas um preceito da autonomia privada, com o qual as partes pretendem regular os seus interesses, nas relações entre elas ou com terceiros, em vista de escopos práticos de caráter típico, socialmente valoráveis pela sua constância e regularidade na vida de relações corrente. ${ }^{31}$

Assim, deve ser adotada com a devida prudência a compreensão de função social em que "o contrato é submetido a novos elementos integradores de relevância à sua formação, existência e execução, superando a esfera consensual" 32 .

Nessa diretriz, o Superior Tribunal de Justiça deu provimento parcial, por unanimidade de votos, ao Recurso Especial interposto pela Coelba por entender que a concepção de função social do contrato não perfaz a aniquilação da autonomia da vontade, tão somente, abranda-a. Em suma, o STJ esclarece que a função social do contrato não pode implicar em desrespeito ao término do prazo do contrato, pois fora livremente pactuado entre as partes.

Importa destacar dois fragmentos da decisão proferida pelo STJ, os quais traduzem a interpretação da função social do contrato em consonância com o nosso entendimento:

\footnotetext{
${ }^{31}$ BETTI, Emilio. Teoria geral do negócio jurídico/ Emílio Betti; tradução Ricardo Rodrigues Gama. Campinas: LZN Editora, 2003, p. 247-248.

32 ALVES, Jones Figueirêdo. Código Civil Comentado / coordenadora Regina Beatriz Tavares da Silva. 9.ed. de acordo com a Lei n. 12.607/2012 e ADF 132 e ADI 4.277. São Paulo: Saraiva, 2013, p. 425.
} 
O exame da função social do contrato é um convite ao Poder Judiciário, para que ele construa soluções justas, rente à realidade da vida, prestigiando prestações jurisdicionais intermediárias, razoáveis, harmonizadoras e que, sendo encontradas caso a caso, não cheguem a aniquilar nenhum dos outros valores que orientam o ordenamento jurídico, como a autonomia da vontade. (...) O acórdão recorrido extrapolou os limites do art. 421 do CC/02, fazendo com que a função social prevaleça sem quaisquer condicionamentos, aniquilando a liberdade de contratar. Na realidade, nesse contexto, a função social deve-se limitar ao papel de flexibilizar e limitar a autonomia da vontade. ${ }^{33}$

Com efeito, para a correta inteligência da função social do contrato é preciso ponderar a profundidade e a responsabilidade social dos contratantes aliada às suas aspirações individuais insertas no negócio, em respeito à funcionalização do pacto e, simultaneamente, à autonomia da vontade.

\section{A FUNĈ̃O SOCIAL DOS CONTRATOS SOB A ÓTICA DA EFICIÊNCIA ECONÔMICA}

\subsection{O PARADIGMA DA EFICIÊNCIA ECONÔMICA}

Evidenciou-se no capítulo anterior o entendimento de parcela significativa da doutrina brasileira, para a qual a função social dos contratos visa puramente tutelar os hipossuficientes nas relações contratuais. Entretanto, há de se questionar se compete ao diploma de direito privado distribuir benesses e promover justiça social. Assim, surge a dúvida se a adoção de tal entendimento não prejudica a liberdade de dispor dos próprios interesses e, por conseguinte, o próprio ideal do contrato.

\footnotetext{
${ }^{33}$ STJ, RESP 972.436 - BA (2007/0179867-7), $3^{\text {a }}$ T, Min. Relatora NANCY ANDRIGHI, DJe 12.06.2009.
} 
O objetivo deste capítulo é analisar a função social do contrato compreendida sob a ótica da eficiência econômica, a qual não ignora a relevância do interesse social na relação contratual, entretanto, distingue o interesse coletivo e a proteção da parte mais fraca, visando a resguardar as relações de mercado que são estruturadas nas expectativas dos agentes econômicos.

Trocando em miúdos, entramos aqui em nossa tese original que busca defender a função social do contrato não apenas como instrumento de uma justiça distributiva, mas, também, de uma justiça econômica, sendo essa última perspectiva muito mais incipiente em nosso direito nacional.

$\mathrm{Na}$ ponderação de Gerson Luiz Carlos Branco, tem-se que "na concepção posta no artigo 421, o individual e o social complementam-se, afirmando a força do homem e dos bens culturais no processo histórico, cujo sentido é adquirido em razão de sua historicidade e a participação na vida social" 34 . Nesta perspectiva, o que se pretende é a correta adaptação aos contornos do instituto supramencionado, para que, deste modo, a funcionalização do contrato respeite os interesses das partes negociais e o espaço público de mercado.

A concepção da função social do contrato, ora apresentada, tem como escopo acautelar os interesses sociais inerentes à relação contratual sem, no entanto, negligenciar o ambiente em que essa relação é celebrada, qual seja: o mercado. Nas palavras de Ronald Coase, um dos fundadores da Escola Econômica do Direito, o mercado "é a instituição que existe para facilitar a troca de bens e serviços, isto é, existe para que se reduzam os custos de se efetivarem operações de trocas" 35.

Nessa diretriz, a Magna Carta de 1988 consagra a economia de livre mercado ao instituir uma ordem econômica pautada na liberdade de iniciativa econômica e no direito de propriedade privada dos meios de produção.

\footnotetext{
${ }^{34}$ BRANCO, Gerson Luiz Carlos. As origens doutrinárias e a interpretação da função social dos contratos no código civil brasileiro. Tese de Doutorado apresentada à Universidade Federal do Rio Grande do Sul - UFRGS, sob a orientação da Professora Judith Hofmeister Martins-Costa. p. 228. Disponível em: http://www.lume.ufrgs.br/handle/10183/7486. Acessado em 12.01.2015.

${ }^{35}$ COASE, Ronald. The firm, the Market and the law apud TIMM, Luciano Bentetti. Função Social do Direito Contratual no Código Civil Brasileiro: Justiça Distributiva VS. Eficiência Econômica. RIDB, Ano 1 (2012). N. 6.
} 
A este respeito, Dirley da Cunha Júnior sustenta:

De efeito, malgrado tenha a Constituição de 1988 consagrado uma economia de livre mercado, de natureza capitalista - porque instrumentalizou uma ordem econômica apoiada na apropriação privada dos meios de produção e na livre iniciativa econômica e privada -, institui ela numerosos princípios limitando e condicionando o processo econômico, no intuito de direcioná-lo a proporcionar o bem-estar social ou melhoria da qualidade de vida. O primeiro - e de todos o mais importante -, em direção ao qual todos os demais princípios se encaminham e se encontram, está consubstanciado como o próprio fim da ordem econômica: assegurar a todos existência digna, conforme os ditames da justiça social. A legitimidade da ordem econômica brasileira, portanto, está condicionada à realização daquele fim. Para que esse fim seja alcançado, entretanto, há outros condicionamentos conformadores do processo produtivo, que a Constituição tratou como princípios gerais da atividade econômica (art. 170, I a IX) (...). ${ }^{36}$

Nesse contexto, importa mencionar que a Constituição consagrou um modelo de Estado intervencionista para viabilizar e concretizar uma ordem econômica permeada pelos ditames da justiça social atrelada aos demais elementos conformadores do processo produtivo. $\mathrm{O}$ artigo 174, caput, da Constituição Federal, prevê a intervenção indireta do Estado que atuará como agente normativo e regulador da atividade econômica.

Firme em tais lineamentos, o legislador introduziu no atual Código Civil o artigo 421, o qual reconhece o valor social do contrato. Em razão da fluidez e da flexibilidade do conteúdo presente no instituto supramencionado, o intérprete da norma deverá realizar a sua atividade com parcimônia não descurando o real intuito do legislador. Assim, o que se pretende é evitar as distorções nos contornos da função social dos contratos, bem como rechaçar o comportamento oportunista daqueles que pretendem enquadrar o interesse social como o interesse da parte mais frágil da relação

\footnotetext{
${ }^{36}$ CUNHA JÚNIOR, Dirley. Curso de Direito Constitucional. 4. ed. rev., atual. Bahia: Jus Podivm. 2010. p. 1185-1186.
} 
contratual, sem ao menos observar os reflexos ao espaço público de mercado e por todos os demais agentes integrantes deste mesmo mercado.

Considerando a importância da complementaridade do interesse individual e social dos contratos, Miguel Reale pondera:

A dialética da complementaridade condiciona os dois fatores "liberdade individual" e "socialidade" numa relação permanente e progressiva que impede a compreensão de um sem o outro, pois formam uma unidade concreta da relação que constituem. Essa complementaridade desdobra-se numa perspectiva de coimplicação e de funcionalidade, que garante uma totalidade de sentido ao contrato como elemento integrante do mundo cultural. ${ }^{37}$

Deste modo, inegável o papel do contrato para a sociedade, o qual irá dirigir-se para a consecução das finalidades das partes negociais e aos interesses da coletividade simultaneamente. Não é demais lembrar as palavras de Calixto Salomão Filho acerca da orientação contida no artigo 421 do Código Civil, para o qual a boa interpretação do instituto "pode transformar-se, portanto, em poderoso canal de proteção da sociedade civil e controle social da atividade empresarial e civil" 38 .

Com efeito, se faz imprescindível a delimitação da compreensão do artigo 421 do Código Civil alinhada aos ditames de justiça social proclamado pela Constituição, mas também atentos aos interesses individuais (expressão da autonomia da vontade e inerente ao contrato privado) porque, a interpretação equivocada desta norma acarretará vultosos custos de transação, vez que serão repassados aos demais agentes atuantes no mercado.

Assim, a funcionalização do contrato traduzida como proteção da parte mais frágil da relação contratual, não ponderando a interação com os demais agentes presentes no espaço público de mercado, conduzirá a

\footnotetext{
${ }^{37}$ REALE, Miguel. Experiência e Cultura. p. 180-185. apud BRANCO, Gerson Luiz Carlos. As origens doutrinárias e a interpretação da função social dos contratos no código civil brasileiro. Tese de Doutorado apresentada à Universidade Federal do rio Grande do Sul-UFRGS, sob a orientação da Professora Judith Hofmeister Martins-Costa. p. 228. Disponível em: http://www.lume.ufrgs.br/handle/10183/7486. Acessado em 12.01.2015.

38 SALOMÃ̃ FILHO, Calixto. Função Social do Contrato: Primeiras anotações. Revista de Direito Mercantil, Industrial, Econômico e Financeiro, v.132, São Paulo: Malheiros, 2003, p. 24.
} 
externalidades negativas. Nesse sentido, "a parte protegida está externalizando os custos aos demais devedores para o seu próprio benefício, resultando em situação socialmente ineficiente" 39 .

Repelindo a ideia de função social dos contratos como instrumento de justiça distributiva, Rachel Sztajn afirma:

Será que um código de direito privado - mesmo que seja visto como a constituição do homem comum, na dicção de Miguel Reale - deve conter dispositivos que induzam as pessoas a agirem tendo em vista interesses do Poder Público? Esse é o sentido que se dava à expressão 'função social' no ordenamento italiano à época do fascismo. (...) Normas jurídicas de expresso viés ideológico ou político-ideológico e regimes democráticos capitalistas combinam mal; elas atendem melhor aos interesses do Poder nos regimes ditatoriais, em que o Governo, confundido com o Estado, crê saber melhor que qualquer cidadão, o que convém a todos e a cada um. ${ }^{40}$

Faz-se importante registrar a dupla perspectiva sobre a qual a função social dos contratos pode ser tratada: a primeira sustenta a funcionalização do contrato como meio de justiça social; a segunda reforça que o contrato perfaz uma transação de mercado, na qual deverão ser observados e harmonizados os interesses individuais e coletivos, para que não haja lesão ao espaço público de mercado. Assim, importa realizarmos uma reflexão acerca dos efeitos deletérios que a interpretação equivocada do artigo 421 do Código Civil poderá acarretar ao mercado e ao ordenamento jurídico, dessa forma, a atividade exegética poderá ser realizada com prudência e ser efetivamente a expressão dos anseios do legislador.

\footnotetext{
39 TALLEY, Eric. Contract renegotiation, mechanism design, and the liquidated damages rule, $\mathrm{p}$. 1214-1215. Apud TIMM, Luciano Betti. Função Social do Direito Contratual no Código Civil Brasileiro: Justiça Distributiva VS. Eficiência Econômica. RIDB, Ano 1 (2012). Nº 6.

${ }^{40}$ SZTAJN, Rachel. Função social do contrato e direito de empresa. Revista de direito Mercantil, ano XLIV, n.139. São Paulo: Malheiros, jul./set.2005, p.30 e 49.
} 


\subsection{ANÁLISE JURISPRUDENCIAL ACERCA DO PARADIGMA DA EFICIÊNCIA ECONÔMICA}

Com o advento do atual Código Civil pautado na diretriz de socialidade do direito, novos institutos foram inseridos, estimulando o entendimento dos Tribunais brasileiros acerca dos novos regramentos jurídicos. O artigo 421 do Código Civil ao dispor "a liberdade de contratar será exercida em razão e nos limites da função social do contrato", apresentou interpretações controvertidas do instituto, deste modo, fez-se necessária à manifestação do judiciário acerca da função social dos contratos e seus conflitantes paradigmas: justiça distributiva versus eficiência econômica.

Neste momento, vale relembrar o representativo caso da "Soja Verde" analisado no capítulo anterior, em que os efeitos deletérios da intervenção judicial nos contratos restaram evidenciados, uma vez que, a nosso ver, a adoção da função social dos contratos, a partir de uma ideia de justiça distributiva, mostrou-se inadequada.

Conforme mencionamos no capítulo anterior, os contratos de venda antecipada de soja à indústria apresentaram aumento no preço, no entanto, não houve divisão destes valores com os produtores, os quais invocaram a função social dos contratos como fundamento para a revisão dos contratos.

Alguns destes casos reverberaram no Superior Tribunal de Justiça, deste modo, ao analisar o teor do artigo 421 do Código Civil e respectiva função social dos contratos, adotou-se a perspectiva pautada na eficiência econômica, revertendo as decisões proferidas pelo Tribunal de origem. Vejamos a ementa do Recurso Especial 803.481-GO:

Direito civil e agrário. Compra e venda de safra futura a preço certo. Alteração do valor do produto no mercado. Circunstância previsível. Onerosidade excessiva. Inexistência. Violação aos princípios da função social do contrato, boa-fé objetiva e probidade. Inexistência. - A compra e venda da safra futura, preço certo, obriga as partes se o fato que alterou valor do produto agrícola não era imprevisível. - Na hipótese afigura-se impossível admitir onerosidade excessiva, inclusive porque alta do dólar em virtude das eleições presidenciais e da iminência de guerra no Oriente Médio - motivos alegados pelo recorrido para sustentar a ocorrência de acontecimento extraordinário - 
porque são circunstâncias previsíveis, que podem ser levadas em consideração quando se contrata a venda para entrega futura com preço certo. - $O$ fato do comprador obter maior margem de lucro na revenda, decorrente da majoração do preço do produto no mercado após a celebração do negócio, não indica a existência de má-fé, improbidade ou tentativa desvio da função social do contrato. - A função social infligida ao contrato não pode desconsiderar seu papel primário e natural, que é o econômico. Ao assegurar a venda de sua colheita futura, é de se esperar que o produtor inclua nos seus cálculos todos os custos em que poderá incorrer, tanto os decorrentes dos próprios termos do contrato, como aqueles derivados das condições da lavoura. - A boa-fé objetiva se apresenta com uma exigência de lealdade, modelo objetivo de conduta, arquétipo social pelo qual impõe o poder-dever de que cada pessoa ajuste a própria conduta e modelo, agindo como agira uma pessoa honesta, escorreita e leal. Não tendo comprador agido de forma contrária a tais princípios, não há como inquinar seu comportamento de violador da boa-fé objetiva. Recurso Especial conhecido e provido. ${ }^{41}$ (Grifos nossos).

Corroborando do entendimento acima exposto, Ribeiro e Galeski Júnior sustentam que "nos contratos empresariais, o risco não pode ser considerado elemento estranho, ao contrário, a atividade econômica é uma atividade de risco, remunerada pelo lucro e ágio, não se justificando a invocação e a aceitação das normas gerais dos contratos com o propósito de neutralização do risco" ${ }^{42}$. Neste passo, prosseguem afirmando que: "nos contratos empresariais, acrescenta-se a relação existente entre segurança, estabilização e crédito quando da invocação do princípio, tornando mais complicada a tarefa de definição de sua função”.

41 STJ, $3^{\mathrm{a}}$ T. REsp.803.481-GO, Rel. Min. Nancy Andrighi. Disponível em: https://ww2.stj.jus.br/processo/revista/documento/mediado/?componente=ATC\&sequencial $=3139936 \&$ num_registro $=200502058570 \&$ data $=20070801 \&$ tipo $=5 \&$ formato $=$ PDF. Acessado em 18.01.2015.

42 RIBEIRO, Marcia Carla Pereira, 1964. Teoria Geral dos Contratos: contratos empresariais e análise econômica/ Marcia Carla Pereira Ribeiro, Irineu Galeski Júnior. - Rio de Janeiro: Elsevier, 2009, p.164-165. 
Evidencia-se a prudência do STJ ao analisar o presente caso e, deste modo, é possível inferir do julgado supratranscrito que as peculiaridades dos contratos negociais foram sopesadas, reforçando a tutela do crédito e privilegiando a segurança das relações contratuais.

Imperioso afirmar que a flexibilidade sistemática do Código Civil, permeada por cláusulas abertas, confere ao magistrado o exercício da atividade exegética para realizar o correto delineamento destas normas. Frise-se, no entanto, que o preenchimento destes regramentos jurídicos não pode ser realizado indiscriminadamente, assim, deve-se se levar em consideração os anseios do legislador no ato de elaboração normativa, sob pena de esvaziar o seu conteúdo prático.

A este respeito, cumpre salientar as lições de Ribeiro e Galeski Júnior:

Desta feita, a constitucionalização das relações privadas e a consagração do seu caráter social não podem tomar as atenções de forma a concentrar toda esperança e atuar como principal mecanismo de implementação de políticas públicas que conduzam aos objetivos centrais elencados na Constituição Federal, isentando-se, por exemplo, o Poder Público de sua missão. ${ }^{43}$

Os mesmos autores, com arrimo em Comparato, afirmam ainda:

Também quando se pensa a função social da empresa, a adoção desta tese não deve servir de 'disfarce retórico para o abandono, pelo Estado, de toda política social', pois, quando a 'Constituição define como objetivo fundamental de nossa República construir uma sociedade livre, justa e solidária $\left(\operatorname{art} .3^{\circ}, \mathrm{I}\right)$, quando ela declara que a ordem social tem por objetivo a realização do bem-estar e da justiça social (art.193), ela não está certamente autorizando uma demissão do Estado, como órgão encarregado de guiar e dirigir a nação em busca de tais finalidades', em proveito de uma

\footnotetext{
${ }^{43}$ RIBEIRO, Marcia Carla Pereira, 1964. Teoria Geral dos Contratos: contratos empresariais e análise econômica/ Marcia Carla Pereira Ribeiro, Irineu Galeski Júnior. - Rio de Janeiro: Elsevier, 2009, p. 169.
} 
funcionalização de institutos privados como são as sociedades e os contratos. ${ }^{44}$

Sensível a tudo quanto foi exposto, insta mencionar que são escassos os casos concernente à função social dos contratos empresariais sob o paradigma da eficiência econômica que reverberaram no STJ. Isto porque, o paradigma em comento é proveniente dos Estados Unidos, onde o movimento conhecido como "Law and Economics" analisa o ordenamento jurídico à luz de sua lógica econômica e da diminuição de seus custos.

Cumpre advertir que no Brasil a construção do paradigma da eficiência econômica é recente, assim, Luciano Benetti Tim ${ }^{45}$, defensor desta teoria, aponta outros autores renomados adeptos desta corrente, dentre eles: Rachel Sztajn, Décio Zylbersztajn, Armando Castelar Pinheiro e Jairo Saddi.

À guisa de exemplificação, cumpre registrar as palavras de Rachel Sztajn, defensora ferrenha da função social dos contratos à luz da eficiência econômica:

A função social do contrato tem de conviver com a dinâmica dos mercados; objetivo das normas de direito positivo, e também das sociais, seria diminuir riscos e estimular o cumprimento das promessas como forma de facilitar a continuidade da atividade econômica. Por isso é que se pensa em regramento flexível, que estimule a confiança na acordada distribuição dos riscos inerentes às operações de longo prazo e de execução continuada que aparecem no lado da oferta, sem o quê a probabilidade de elevação dos custos de transação e, no limite, de desestímulo a operações é não-desprezível. ${ }^{46}$

${ }^{44}$ COMPARATO, Fábio Konder. Estado, empresa e função social. Revista dos tribunais. v.731, São Paulo: Revista dos Tribunais, 1996. Apud RIBEIRO, Marcia Carla Pereira, 1964. Teoria Geral dos Contratos: contratos empresariais e análise econômica/ Marcia Carla Pereira Ribeiro, Irineu Galeski Júnior. - Rio de Janeiro: Elsevier, 2009.p. 170.

45 TIMM, Luciano Benetti. Função Social do Direito Contratual no Código Civil Brasileiro: Justiça Distributiva VS. Eficiência Econômica.

46 SZTAJN, Rachel. Função social do contrato e direito de empresa. Revista de direito Mercantil, ano XLIV, n.139. São Paulo: Malheiros, jul./set.2005, p 39. 
Com efeito, malgrado a ideia de função social dos contratos sob a égide da eficiência econômica seja incipiente em nosso ambiente jurídico, a abordagem da análise econômica diante o direito contratual deve ser tratada com a devida relevância. O presente paradigma - eficiência econômica - identificou os efeitos deletérios que a interpretação usualmente amparada pelos Tribunais e doutrina nacionais estava acarretando ao espaço público de mercado ao aplicar a função social dos contratos como sinônima da proteção da parte mais frágil da relação contratual.

Inspirado na abordagem econômica do direito, Rodrigo Garcia da Fonseca realiza as seguintes ponderações:

i) A dignidade humana não pode ser banalizada como vem sendo e que o descumprimento da palavra empenhada, salvo justa causa, é verdadeira indignidade;

ii) A função primordial do contrato continua sendo a econômica, mesmo nos países socialistas. A diferença é que nesses países o Estado é que dita como devem ser pautados, redigidos e cumpridos os contratos, ou seja, tem-se verdadeiro contrato dirigido;

iii) A liberdade de contratar é o motor da economia, e tanto o contrato como a propriedade privada devem ser protegidos por regras claras, estáveis e preestabelecidas;

iv) Além da economicidade, ou seja, da razoabilidade econômica na aplicação da lei aos contratos, impõese também a busca da eficiência. (...). O fundamental hoje é a flexibilidade do direito para atender às finalidades específicas de cada situação;

v) A função social do contrato não pode anular a sua função econômica e só deve ser aplicada quando foi estritamente necessária e levando-se em consideração os princípios da economicidade, razoabilidade e proporcionalidade, sem falar nos potenciais efeitos jurídicos que sua aplicação pode vir a causar. ${ }^{47}$

${ }^{47}$ FONSECA, Rodrigo Garcia da. A função social do contrato e o alcance do artigo 421 do Código Civil. Rio de Janeiro: Renovar, 2007 apud BERALDO, Leonardo de Faria. Função Social do 
Não obstante o acima exposto, o objetivo do presente trabalho é demonstrar as duas óticas sobre a qual a função social dos contratos pode ser entendida, para que, deste modo, o preenchimento da cláusula aberta inserta no artigo 421 do Código Civil seja realizada com parcimônia, respeitando os ditames de justiça social preconizados por nossa Carta Magna, mas, também, considerando os demais preceitos nela consubstanciados, tal como a economia de livre mercado.

\section{A INTERVENÇÃO JUDICIAL NOS CONTRATOS E AS IMPLICAÇÕES DOS PARADIGMAS CONFLITANTES: JUSTIÇA DISTRIBUTIVA VERSUS EFICIÊNCIA ECONÔMICA}

A inovação operada pelo Código Civil de 2002, ao proclamar o comando de socialidade às relações privadas, confere uma unidade de tratamento ao sistema. Nessa diretriz, o legislador pretendendo implantar o ideal de constitucionalização do direito privado e o faz por meio de cláusulas abertas, as quais clamam por uma função exegética ponderada do magistrado.

O Direito Civil Constitucional visa consagrar os ideais presentes em um Estado Democrático de Direito, o qual prima pelo resguardo de direitos sociais e individuais, pela liberdade, segurança e justiça, dentre outros valores.

Sustenta Carlos Ayres Britto que a democracia:

É o nome que assenta para o fenômeno da subida do povo ao podium das decisões coletividade de caráter imperativo a simbolizar que ele mesmo é quem escreve a sua história de vida político-jurídica e assim toma as rédeas do seu próprio destino. ${ }^{48}$ (grifo nosso)

Contrato: Contributo para a Construção de uma Nova Teoria. Belo Horizonte: Del Rey, 2011. p.106-107.

48 BRITTO, Carlos Ayres. Teoria da Constituição. Rio de Janeiro: Forense, 2006. p. 183 apud SILVA, Geocarlos Augusto Cavalcante da. Democracia e Ativismo Judicial. Revista de Direito Privado. Ano 12, vol. 46, abr-jun. 2011, p.45. 
Infere-se da afirmação acima que a liberdade constitui um dos valores fundantes da democracia. Sob a égide do direito privado, em especial do direito contratual, o valor "liberdade" é estimado na celebração do negócio jurídico, em que as partes contratantes, livre e consensualmente, harmonizam as suas vontades para atingir os seus objetivos de cunho patrimonial.

No Estado Democrático de Direito, o princípio da legalidade apresenta-se como o mais importante instrumento constitucional de proteção individual. Neste contexto, pretende-se demonstrar que a função hermenêutica realizada pelo intérprete ao concretizar os preceitos inseridos nas cláusulas abertas está subordinada aos contornos traçados pelo legislador.

Não obstante a fluidez das cláusulas abertas, o que naturalmente inspira a atividade interpretativa do magistrado, tem-se que as aspirações contidas na atividade legiferante, ao produzir as referidas cláusulas, devem ser observadas, sob pena de afrontar o princípio da separação dos poderes.

Atento a isto, Geocarlos Augusto Cavalcante da Silva preleciona:

Ultrapassados os limites, isto é, agindo o Judiciário não para compor conflitos, individuais ou coletivos, ou qulaquer outra função permitida/concedida pela legislação, constitucional ou infraconstitucional, haverá indevida intromissão e, por consequência, violação ao princípio da separação dos poderes. Todavia, aqui não será um problema de judicialização da política ou politização do Judiciário, mas de exercício fora dos limites estabelecidos na legislação e, portanto, sem legitimidade, legal ou política. ${ }^{49}$

Com efeito, o atual Código Civil, ao preconizar o preceito constitucional de socialidade por meio de cláusulas abertas, convida o magistrado a desenvolver a atividade exegética para aflorar os contornos ansiados pelo legislador no momento de elaboração da norma. Entretanto, Maria Celina Bodin de Moraes alerta para a dificuldade do magistrado em realizar a interpretação adequada e ponderada nos seguintes termos:

\footnotetext{
49 SILVA, Geocarlos Augusto Cavalcante da. Democracia e Ativismo Judicial. Revista de Direito Privado. Ano 12, vol. 46, abr-jun. 2011, p.61.
} 
Não foram ainda, como se sabe, elaborados critérios (ou mesmo parâmetros) minimamente objetivos que possam auxiliar o juiz nessas difíceis matérias, atribuídas, inteiramente, à sua consciência. A jurisprudência, ainda inexperiente no tocante a tal metodologia, tem tido que aplicar sem o necessário apuro técnico, o que contribui para o cenário atual de caos e arbitrariedade em relação ao tema. ${ }^{50}$

No que concerne a aplicação do artigo 421 do Código Civil, verificou-se que a funcionalização do contrato pode ser pautada por dois paradigmas distintos: Justiça Distributiva e Eficiência Econômica.

O primeiro paradigma pretende realizar justiça social por meio do contrato, desta forma, o interesse social equivale ao interesse da parte mais frágil da relação contratual. De outro lado, o paradigma da Eficiência Econômica enaltece o interesse social que deve estar presente em todo e qualquer contrato, mas não se esquece da função econômica nele manifestada, privilegiando a liberdade negocial das partes.

Releva notar que o exame realizado sobre as escassas decisões que adotam uma perspectiva efetivamente econômica da função social, apontou os efeitos deletérios ocasionados ao espaço público de mercado em razão de uma interpretação equivocada desse princípio. Por esta razão, o magistrado não pode julgar somente baseado na sua consciência, devendo sopesar os dispositivos jurídicos inerentes ao tema, bem como as interpretações a eles atribuídas, para que, deste modo, seja capaz de detectar qual a melhor maneira de solucionar o caso concreto.

Assim, a afirmação do respeitável Ministro Humberto Gomes de Barros enseja cautela:

Não me importa o que pensam os doutrinadores. Enquanto for Ministro do STJ, assumo a autoridade da minha jurisdição. O pensamento daqueles que não são Ministros deste Tribunal importa como orientação. A eles, porém, não me submeto (...). Esse é o pensamento do STJ, e a doutrina que se amolde a ele. É fundamental expressarmos o que somos. Ninguém

\footnotetext{
${ }^{50}$ MORAES, Maria Celina Bodin de. Do juiz boca-da-lei à lei segundo a boca-do-juiz: Notas sobre a aplicação-interpretação do direito no início do século XXI. Revista de Direito Privado. Ano 14, vol. 56, out.-dez./2013.p.12-13.
} 
nos dá lições. Não somos aprendizes de ninguém. Quando viemos para este Tribunal, corajosamente assumimos a declaração de que temos o notável saber jurídico - uma imposição da Constituição Federal. Pode não ser verdade. Em relação a mim, certamente, não é, mas, para efeitos constitucionais, minha investidura obriga-me a pensar que assim seja. ${ }^{51}$

Reconhece-se que as cláusulas abertas, tal como a contida no artigo 421 da legislação civil, inspira uma atividade exegética potencializada. Contudo, isto não confere ao magistrado liberdade total para julgar, pautando-se somente em suas concepções pessoais, pois isto implicaria na aplicação arbitrária de sua visão de Justiça.

Não é de se olvidar o teor do artigo 93, inciso IX, da Carta da República, o qual determina que as decisões emanadas pelo Poder Judiciário devam ser fundamentadas. Veja que o intuito desta prescrição constitucional é justamente coibir as decisões tirânicas, em descompasso com o ordenamento jurídico.

Sensível às noções acima expostas, impõe-se concluir que a atividade exegética do magistrado objetiva trazer a lume o real significado das cláusulas abertas - em especial do artigo 421 do Código Civil. No entanto, esta atividade deve ser pautada nos lineamentos apresentados pelo legislador no exercício da sua atividade legiferante, bem como no ordenamento jurídico em sua completude. E não é só: deverão, ainda, ser analisadas todas as interpretações possíveis para alcançar a melhor solução ao caso em concreto.

A reflexão posta é tratada com maestria por Habermas, para o qual:

A aceitação racional das decisões judiciais é guiada pela qualidade dos argumentos levantados, cuja verificação permite que o processo argumentativo seja

\footnotetext{
${ }^{51}$ STJ, AgRg em EDiv no REsp 279.889/AL, $1{ }^{\text {a }}$ Seção, j. 14.08.2002, rel. Min. Francisco Peçanha Martins, rel. p/ acórdão Min. Humberto Gomes de Barros, DJU 07.04.2003 apud MORAES, Maria Celina Bodin de. Do juiz boca-da-lei à lei segundo a boca-do-juiz: Notas sobre a aplicação-interpretação do direito no início do século XXI. Revista de Direito Privado. Ano 14, vol. 56, out.dez./2013.p. 13.
} 
concluído quando, desse todo coerente, resultar um acordo racionalmente motivado. ${ }^{52}$

Para os fins deste trabalho, cumpriu-se indagar qual o sentido e conteúdo da expressão "função social do contrato" disposta no artigo 421 do CC, cujo teor é "a liberdade de contratar será exercida em razão e nos limites da função social do contrato". Nessa toada, apresentou-se os dois paradigmas sobre o qual o referido instituto é interpretado, o da Justiça Distributiva e o da Eficiência Econômica. Por fim, restou demonstrado a prudência com a qual a atividade exegética do magistrado deve ser pautada ao ser convidado a intervir no contrato para sanar eventuais irregularidades presentes no negócio jurídico.

A pergunta permanece sem resposta, no entanto, objetivou-se demonstrar os possíveis efeitos que a interpretação de cada paradigma poderá representar ao espaço público de mercado. Além disso, destacamos os efeitos nocivos e inconstitucionais de uma decisão judicial que exorbite as linhas demarcatórias do instituto previsto no artigo 421 do Código Civil: a função social dos contratos.

Em síntese, tem-se que a solução definitiva para as controvérsias doutrinárias e jurisprudenciais acerca do tema é improvável. Diante do que já foi apresentado, percebe-se que a norma predisposta no artigo 421 do CC apresenta uma grande dúvida em relação à correta interpretação da expressão função social, o presente trabalho destinou-se a demonstrar os dois principais espectros sobre o qual a função social dos contratos pode ser observada. Ainda neste recinto, procurou-se demonstrar os potenciais efeitos lesivos que a adoção desarrazoada do paradigma da justiça distributiva poderá acarretar ao ambiente de mercado, vez que as decisões judiciais analisadas evidenciaram a elevação dos custos de transação e o favorecimento de comportamento oportunista ao tutelar o hipossuficiente de maneira desconexa aos interesses individuais esposados no momento da celebração do contrato.

Em feliz representação, Rachel Sztajn consolida a interpretação da função social dos contratos que nos parece defensável:

\footnotetext{
52 HABERMAS, Jürgen. Between facts and norms: contributions to a discourse theory of law democracy. Cambridge: MIT Press, 1988. P. 222 e ss. apud MORAES, Maria Celina Bodin de. Do juiz boca-da-lei à lei segundo a boca-do-juiz: Notas sobre a aplicação-interpretação do direito no início do século XXI. Revista de Direito Privado. Ano 14, vol. 56, out.-dez./2013.p.28.
} 
Assim é que o regime capitalista, de mercado, mesmo com as restrições - dignidade da pessoa humana e justiça social-, não implica abandono da livre iniciativa no plano econômico, da assunção de riscos e da apropriação privada dos benefícios produzidos. ${ }^{53}$

Oportuno anotar, à guisa de conclusão, que o contrato perfaz a livre manifestação dos particulares, os quais decidem consensualmente vincular-se para dispor sobre seus interesses. Nada obstante a fluidez do artigo 421 do diploma civil tem-se que a atividade hermenêutica a ser realizada pelo magistrado, para o escorreito alcance da expressão função social dos contratos, deverá ser imbuída de cautela, harmonizando os interesses individuais e sociais insertos no contrato e, por conseguinte, colimando os comportamentos oportunistas e os desequilíbrios no ambiente de mercado.

\section{CONCLUSÃO}

A função social do contrato, presente no polêmico artigo 421 do Código Civil, foi apresentada sob duas óticas conflitantes, quais sejam: justiça distributiva e eficiência econômica.

Nessa diretriz, pretendeu-se demonstrar que a textura fluida contida no referido instituto provoca o magistrado a realizar a sua complementação, estimulando a sua atividade interpretativa. Todavia, salientamos que uma interpretação equivocada poderá acarretar diversos prejuízos ao espaço público de mercado, pois poderemos chegar ao absurdo de desvirtuar a própria concepção do instituto "contrato”, na hipótese de inobservância dos interesses individuais.

Constatou-se que a posição predominante entre os juristas brasileiros é aquela que identifica a função social dos contratos como instrumento de aplicação de justiça social, como forma de manifestação da publicização do direito privado. Assim, é possível verificar a exaltação dos ditames da justiça social ao interpretar a função social como proteção à parte mais frágil da relação contratual.

\footnotetext{
53 SZTAJN, Rachel. Função social do contrato e direito de empresa. Revista de direito Mercantil, ano XLIV, n.139. São Paulo: Malheiros, jul./set.2005, p 39.
} 
Defendeu-se, contudo, o paradigma da eficiência econômica, o qual preconiza a harmonização dos interesses sociais e individuais inseridos no contrato. Isto porque, segundo esta perspectiva, o interesse social não se equivale ao interesse da parte mais frágil do contrato, mas sim ao interesse da totalidade de pessoas que integram, efetivamente ou potencialmente, o espaço público de mercado.

Nessa contextualização, realizou-se análise de julgados relevantes que reverberaram no Superior Tribunal de Justiça a fim de demonstrar os possíveis reflexos que a interpretação da função social dos contratos poderá acarretar no ambiente de mercado.

Em relação à intervenção do juiz nos contratos, suscitou-se a máxima cautela no desenvolvimento da atividade exegética, clamando por uma interpretação macroeconômica do contrato empresarial.

À guisa de conclusão, releva mencionar o entendimento de Joaquim de Sousa Ribeiro, com o qual concordamos, "a concepção funcional do contrato serve como meio de autodeterminação e de regulação dos processos sociais de cooperação e troca, competindo-lhe realizar de maneira simultânea o útil, o livre e o justo" 54 . Evidencia-se que esta concepção preserva o contrato em sua integralidade, vez que os valores "liberdade individual" e "socialidade" se complementam e formam uma unidade da relação contratual.

\section{REFERÊNCIAS}

ALVES, Jones Figueirêdo. Código Civil Comentado/ coordenadora Regina Beatriz Tavares da Silva - 9.ed. de acordo com a Lei n. 12.607/2012 e ADF 132 e ADI 4.277 - São Paulo: Saraiva, 2013.

BERALDO, Leonardo de Faria. Função Social do Contrato: Contributo para a Construção de uma Nova Teoria. Belo Horizonte: Del Rey, 2011.

BETTI, Emilio. Teoria geral do negócio jurídico/ Emílio Betti; tradução Ricardo Rodrigues Gama. - Campinas: LZN Editora, 2003.

\footnotetext{
${ }^{54}$ RIBEIRO, Joaquim de Sousa apud BRANCO, Gerson Luiz Carlos. As origens doutrinárias e a interpretação da função social dos contratos no código civil brasileiro. Tese de Doutorado apresentada à Universidade Federal do Rio Grande do Sul - UFRGS, sob a orientação da Professora Judith Hofmeister Martins-Costa. p. 228. Disponível em: http://www.lume.ufrgs.br/handle/10183/7486. Acessado em 12.01.2015.
} 
BRANCO, Gerson Luiz Carlos. As origens doutrinárias e a interpretação da função social dos contratos no código civil brasileiro. Tese de Doutorado apresentada à Universidade Federal do Rio Grande do Sul-UFRGS, sob a orientação da Professora Judith Hofmeister Martins-Costa. Disponível em: http://www.lume.ufrgs.br/handle/10183/7486. Acessado em 12.01.2015.

CUNHA JÚNIOR, Dirley. Curso de Direito Constitucional. 4. ed. rev., atual. Jus Podivm. 2010.

GODOY, Cláudio Luiz Bueno de. A função social do contrato: os novos princípios contratuais. Tese de Doutorado apresentada à PUC-SP, sob orientação do Professor Doutor Renan Lotufo.

GONÇALVES, Carlos Roberto. Direito Civil Brasileiro, volume III: contratos e atos unilaterais / Carlos Roberto Gonçalves. - São Paulo: Saraiva, 2004.

MARTINS-COSTA, Judith. Reflexões sobre o princípio da função social dos contratos. Revista Direito GV, v.1.n.1:(2005):41-66. Disponível em: http://bibliotecadigital.fgv.br/ojs/index.php/revdireitogv/article/view/35261. Acesso em: 14. Dez.2014.

MENDES, Gilmar Ferreira. Curso de direito constitucional/ Gilmar Ferreira Mendes, Inocêncio Mártires Coelho, Paulo Gustavo Gonet Branco. - 4 ed. rev. e atual. - São Paulo: Saraiva, 2009.

MORAES, Maria Celina Bodin de. Do juiz boca-da-lei à lei segundo a boca-dojuiz: Notas sobre a aplicação-interpretação do direito no início do século XXI. Revista de Direito Privado. Ano 14, vol. 56, out.-dez./2013.

NEGREIROS, Teresa. Teoria do contrato: novos paradigmas. $2^{\mathrm{a}}$ ed. Rio de Janeiro: Renovar, 2006.

NERY JÚNIOR, Nelson. Código Civil Comentado/ Nelson Nery Junior, Rosa Maria de Andrade Nery. - 7.ed. ver. ampl. atual. até 25.8.2009. - São Paulo: Editora Revista dos Tribunais, 2009.

REZENDE, Christiane Leles. Pacta Sunt Servanda? Quebra dos Contratos de Soja Verde. Tese de Doutorado apresentada a Faculdade de Economia Administração e Contabilidade da Universidade de São Paulo defendida em 15.02.2008. Disponível em: http://www.teses.usp.br/teses/disponiveis/12/12139/tde-07042008-143732/pt-br.php

RIBEIRO, Marcia Carla Pereira, 1964. Teoria Geral dos Contratos: contratos empresariais e análise econômica/ Marcia Carla Pereira Ribeiro, Irineu Galeski Júnior. - Rio de Janeiro: Elsevier, 2009, p.164-165.

SALOMÃO FILHO, Calixto. Função Social do Contrato: Primeiras anotações. Revista de Direito Mercantil, Industrial, Econômico e Financeiro, v.132, São Paulo: Malheiros, 2003.

SILVA, Geocarlos Augusto Cavalcante da. Democracia e Ativismo Judicial. Revista de Direito Privado. Ano 12, vol. 46, abr-jun.2011.

SZTAJN, Rachel. Revista de Direito Mercantil, Industrial, Econômico e Financeiro. Nova Série- Ano XLIV-n.139-julho-setembro de 2005. São Paulo: Editora Malheiros. 
THEODORO JÚNIOR, Humberto. O contrato e sua função social, 4.ed.rev.atual. e amp. - Rio de Janeiro: Forense, 2014.

TIMM, Luciano Bentetti. Direito, Economia e a função social do contrato: em busca dos verdadeiros interesses coletivos protegíveis no mercado de crédito. Disponível em: http://www.tex.pro.br/home/artigos/78-artigos-abr2007/5581-direito-economia-e-a-funcao-social-do-contrato-em-busca-dosverdadeiros-interesses-coletivos-protegiveis-no-mercado-do-credito. Acesso em 30.12.2014.

TIMM, Luciano Betti. Função Social do Direito Contratual no Código Civil Brasileiro: Justiça Distributiva VS. Eficiência Econômica. RIDB, Ano 1 (2012). $N^{\circ} .6$.

WALD, Arnaldo. Direito Civil: direito das obrigações e teoria geral dos contratos, 2/ Arnaldo Wald; com a colaboração dos professores Seny Glanz, Ana Elizabeth Lapa Wanderley Cavalcanti e Liliana Mirandi Paesani. - 21. ed. - São Paulo: Saraiva, 2013. 